\title{
PENGARUH NILAI PERUSAHAAN, PERTUMBUHAN PERUSAHAAN DAN REPUTASI AUDITOR TERHADAP PERATAAN LABA DI SEKTOR PERBANKAN
}

\author{
Yolanda Zulia Saputri, Robiatul Auliyah, Rita Yuliana \\ Program Studi Akuntansi Universitas Trunojoyo Madura \\ Jl. Raya telang PO.BOX 2 Kamal, Bangkalan - Madura
}

\begin{abstract}
The aim of the research is to find empirical evidence of firm value, growth company and auditor reputation toward income smoothing taken by banking company listed in Indonesia Stock Exchange. Detection of income smoothing in this study using Eckel Index.The research pupulation is companies listed in Indonesia Stock Exchange arround 2013 to 2016. The sampels were taken using purposive sampling method. The analysis tecnique used on this study is binary logistic regresion using SPSS version 2.1.The results show that, (1) firm value have effect toward income smoothing, (2) growth company have effect toward income smoothing, and (3) auditor reputation have no effect toward income smoothing.The coefficient of determination in this study is 0,170, which means $17 \%$ of income smoothing is influenced by independent variables studied, the rest is explained by other variables. This study shows that there are many other variables not examined in this study may explain income smoothing.
\end{abstract}

Keywords:firm value, growth company, auditor reputation, income smoothing

\begin{abstract}
ABSTRAK
Tujuan dari penelitian ini adalah untuk memperoleh bukti empiris pengaruh nilai perusahaan, pertumbuhan perusahaan dan reputasi auditor terhadap perataan laba pada perusahaan perbankan yang terdaftar di BEI. Deteksi perataan laba pada penelitian ini menggunakan Indeks Eckel. Populasi dalam penelitian ini adalah perusahaan perbankan yang terdaftar diBEI periode 2013-2016, sedangkan pengambilan sampel menggunakan metode purposive sampling.Teknik analisis yang digunakan dalam penelitian ini adalah analisis regresi logistik menggunakan program SPSS versi2.1. Hasil pengujian menunjukkan bahwa (1) nilai perusahaan berpengaruh terhadap perataan laba, (2) pertumbuhan perusahaan berpengaruh terhadap perataan laba, dan (3) reputasi auditor tidak berpengaruh terhadap perataan laba. Koefisien determinasi dalam penelitian ini adalah 0,170 yang berarti $17 \%$ praktik perataan laba dipengaruhi oleh variabel independen yang diteliti, selebihnya dijelaskan oleh variabel lainnya. Penelitian ini menunjukkan bahwa masih banyak variabel lain yang tidak diteliti dalam penelitian ini dapat menjelaskan perataan laba.
\end{abstract}

Kata kunci: nilai perusahaan, pertumbuhan perusahaan, reputasi auditor, perataan laba 


\section{PENDAHULUAN}

Laba merupakan salah satu informasi penting yang terkandung dalam laporan keuangan. Pentingnya informasi laba secara tegas telah disebutkan dalam Statement of Financial Concepts (SFAC) No.1. pernyataan tersebut menyatakan bahwa selain untuk menilai kinerja manajemen, laporan keuangan juga membantu manajemen dalam mengestimasi kemampuan laba yang representatif. Selain itu, laporan keuangan juga bermafaat untuk menaksir risiko dalam investasi atau kredit. Namun manfaat tersebut terkadang kurang dirasakan karena investor dan kreditor hanya terpaku pada perolehan laba tanpa memperhatikan prosedur yang digunakan oleh manajemen dalam menghasilkan laba tersebut (Beattie dkk,1994).

Pentingnya informasi laba bagi investor akan mendorong manajemen untuk melakukan tindakan yang membuat laba menjadi lebih baik. Hal tersebut disebabkan angka laba yang stabil menunjukkan keberhasilan kinerja manajemen di mata investor. Berdasarkan pengetahuan tersebut, manajemen mengupayakan cara agar laba menjadi stabil. Salah satu cara yang sering digunakan adalah manipulasi atau direkayasa oleh pihak manajemen yang dikenal dengan istilah manajemen laba (Hwihanus dkk, 2010).

Salah satu pola dari manajemen laba adalah perataan laba (income smoothing). Perataan laba merupakan salah satu upaya manajemen untuk memaksimumkan atau sebaliknya meminimalkan laba. tujuan manajemen laba tersebut adalah agar laba yang dilaporkan terlihat stabil. Menurut teori keagenan (agency theory), perataan laba muncul ketika semua pihak yang terlibat mempunyai dorongan untuk melakukan kepentingannya sendiri-sendiri sehingga timbul adanya konflik antara prinsipal (investor) dan agen (manajer). Manajemen ingin mendapatkan penilaian yang baik dari investor dan juga agar kinerjanya nampak bagus. Di sisi lain, investor menyukai laba yang stabil karena menjadi cermin keamana pertumbuhan investasi mereka. Namun demikian, tindakan perataan laba jika dilakukan dengan cara yang tidak wajar akan dapat menimbulkan adanya kesalahan pengambilan keputusan bagi investor

Praktik perataan laba merupakan fenomena yang umum terjadi sebagai usaha manajemen untuk mengurangi fluktuasi laba yang dilaporkan (Nasir dkk, 2002). Menurut teori keagenan (agency theory), perataan laba muncul ketika semua pihak yang terlibat mempunyai dorongan untuk melakukan kepentingannya sendiri-sendiri sehingga timbul adanya konflik antara prinsipal (investor) dan agen (manajer). Tindakan ini menyebabkan pengungkapan informasi mengenai penghasilan laba menjadi menyesatkan. Oleh karena itu, perataan laba akan mengakibatkan terjadinya kesalahan dalam pengambilan keputusan oleh pihakpihak yang berkepentingan dengan perusahaan, khususnya pihak eksternal (Jatiningrum, 2000).

Praktik perataan laba yang dilakukan oleh perusahaan tidak terlepas dari beberapa faktor yang mempengaruhinya. Beberapa penelitian mengenai faktorfaktor terhadap perataan laba menunjukkan beragam hasil yang berbeda. Faktorfaktor yang dianggap mempengaruhi perataan laba antara lain nilai perusahaan, pertumbuhan perusahaan, dan reputasi auditor. Penelitian Aji dan Mita (2010) menunjukkan bukti tentang adanya pengaruh nilai perusahaan yang diproksikan 
dengan Price per Book Value terhadap perataan laba di perusahaan manufaktur. Hasil penelitian tersebut menemukan bukti bahwa tindakan perataan laba yang dilakukan oleh perusahaan disebabkan oleh semakin tingginya nilai perusahaan. Dengan demikian, semakin tinggi nilai perusahaan maka semakin tinggi tindakan perataan laba.

Perataan laba sebenarnya tidak masalah jika dilakukan secara bertanggung jawab. Hal tersebut disebabkan tindakan perataan laba dapat meminimumkan variabilitas laba dan risiko saham sebuah perusahaan. Perusahaan akan mempertahankan variabilitas laba yang minim agar nilai pasar tetap tinggi dan menarik sumber daya ke dalam perusahaan. Bagi sektor perbankan sendiri sumber dana investasi yang berasal dari penjualan saham maupun surat hutang juga merupakan salah satu sumber pendanaan operasional dalam perbankan (Kasmir, 2012). Hal ini menjelaskan pentingnya akan nilai perusahaan perbankan yang memperdagangkan sahamnya di Bursa Efek Indonesia. Menurut Repi,dkk (2016) setiap Bank dituntut untuk memaksimalkan nilai perusahaan karena semakin tinggi nilai perusahaan maka investor akan semakin tertarik untuk berinvestasi.

Beberapa bukti empiris menunjukkan bahwa perataan laba memerlukan pertimbangan kemampuan perusahaan seperti struktur modal, profitabilitas, dan tingkat pertumbuhan (Cohen dan Zarowin, 2010; Zamri dkk, 2013; dan Farooqi dkk, 2014). Bukti-bukti tersebut menunjukkan bahwa perusahaan yang berkinerja baik berpeluang melakukan perataan laba.

Bukti empiris lain menunjukkan bahwa tindakan perataan laba merupakan pilihan strategi manajer dalam menghadapi perubahan lingkungan bisnis, yaitu implementasi standar akuntansi yang ketat (Kuo dkk, 2014), perubahan tarif pajak (Joosten, 2012), perubahan regulasi (Yu dkk, 2006), dan kompetisi pasar produk (Laksmana dan Yang, 2014). Selanjutnya, beberapa penelitian menunjukkan bukti empiris bahwa manajer melakukan perataan laba karena memiliki sifat oportunis yaitu untuk memaksimalkan bonus (Cohen dan Zarowin, 2010) dan memenuhi ekspektasi analis (Roychouwdhury, 2006; Gunny, 2010; dan Cohen dan Zarowin, 2010).

Ansori (2014) juga melakukan penelitian mengenai pengaruh nilai perusahaan terhadap perataan laba. Hasilnya adalah nilai perusahaan dapat memotivasi manajer untuk melakukan perataan laba. Tindakan perataan laba mempunyai hubungan timbal balik terhadap nilai perusahaan, karena perataan laba menghasilkan berkurangnya fluktuasi laba sehingga dapat mencerminkan stabilitas kinerja perusahaan atau nilai perusahaan. Namun kedua hasil penelitian tersebut tidak sejalan dengan penelitian yang dilakukan oleh Purwanto (2009) bahwa perusahaan yang memiliki nilai perusahaan yang tinggi, kecenderungan melakukan perataan labanya akan semakin rendah. Sulistiyawati (2013) juga berpendapat yang sama bahwa tidak adanya pengaruh nilai perusahaan terhadap perataan laba. Hal tersebut dikarenakan rendah atau tingginya nilai perusahaan tidak menjadi alasan yang cukup bagi perusahaan untuk melakukan perataan laba. 
Pertumbuhan pendapatan juga menjadi faktor adanya perataan laba. Kim dkk (2003) memaparkan bahwa semakin rendah pertumbuhan pendapatan perusahaan, maka kecenderungan untuk memanipulasi juga akan semakin rendah. Hal ini sejalan dengan hasil penelitian Fricilia (2015) yang berhasil membuktikan adanya pengaruh pertumbuhan pendapatan terhadap manajemen laba.

Selanutnya, reputasi auditor merupakan salah satu yang ikut berperan dalam mempengaruhi perataan laba. Handayani (2016) menunjukkan bukti empiris bahwa reputasi auditor berpengaruh terhdap tindakan perataan laba. Hal ini dikarenakan auditor bereputasi baik dianggap dapat mendeteksi kemungkinan terjadinya manajemen secara lebih awal sehingga dapat mengurangi terjadinya praktik perataan laba. Dengan demikian, semakin bereputasi auditornya maka semakin kecil kemungkinan manajer melakukan tindakan perataan laba.

Hasil penelitian tersebut sejalan dengan hasil penelitian Soselisa (2008). Namun hasil yang berbeda ditunjukkan oleh penelitian yang dilakukan Sulistiyawati (2013). Penelitian tersebut menemukan bukti empiris bahwa reputasi auditor tidak menjadi sumber variasi tindakan perataan laba.

Penelitian mengenai perataan laba memiliki beragam hasil dan kesimpulan yang berbeda. Hal ini menjadi menarik bagi peneliti untuk kembali melakukan penelitian guna mengkonfirmasi beberapa hasil penelitian sebelumnya mengenai faktor-faktor yang mempengaruhi perataan laba. Namun, penelitian ini menggunakan perusahaan perbankan yang listing di Bursa Efek Indonesia untuk mendeteksi adanya perataan laba yang masih dilakukan oleh sektor perbankan. Hal tersebut dipicu oleh adanya pengalihan pengawasan dari Bank Indonesia kepada Otoritas Jasa Keuangan sejak tahun 2013. Karena Bank Indonesia seharusnya bertanggung jawab terhadap kualitas informasi, khususnya laba, yang dipublikasikan. Informasi laba tersebut perlu dijaga kualitasnya karena akan menjadi referensi bagi investor dalam membuat keputusan investasinya.

Berdasarkan uraian tersebut, maka rumusan masalah dalam penelitian ini adalah (1) Apakah nilai perusahaan berpengaruh terhadap perataan laba perusahaan perbankan yang terdaftar di BEI? (2) Apakah pertumbuhan perusahaan berpengaruh terhadap perataan laba perusahaan perbankan yang terdaftar di BEI? (3) Apakah reputasi auditor berpengaruh terhadap perataan laba perusahaan perbankan yang terdaftar di BEI?

\section{TINJAUAN PUSTAKA}

\section{Agency Theory (Teori Keagenan)}

Eisenhardt (1989) dalam penelitiannya menjelaskan bahwa teori agensi menggunakan 3 asumsi sifat dasar manusia. Pertama, manusia pada umumnya mementingkan diri sendiri (self interest) sehingga ia akan berusaha sekuat tenaga untuk mencapai kepentingannya, meskipun harus dengan mengorbankan kepentingan orang lain atau yang lainnya. Kedua, manusia memiliki daya pikir terbatas mengenai persepsi masa mendatang (bounded rationality) yang menjadi sumber variasi model pengambilan keputusan. Terakhir, manusia selalu menghindari risiko (risk averse) sehingga mereka berupaya untuk mencaria informasi sebanyak mungkin guna mendapatkan keputusan terbaik yang risikonya paling dapat mereka tanggung. Berdasarkan asumsi sifat dasar manusia tersebut 
dapat dikatakan bahwa manajer sebagai manusia kemungkinan besar akan bertindak berdasarkan sifat opportunistik, yaitu mengutamakan kepentingan pribadinya. Selanjutnya, ketika manajemen bertindak sebagai agen maka seharusnya bertanggung jawab mengoptimalkan keuntungan pemilik dan bertindak untuk kepentingan pemilik namun sebaliknya mereka justru termotivasi untuk mendapatkan keuntungan pribadinya, misalnya memperoleh kompensasi.

Jensen dan Meckling (1976) menjelaskan bahwa konflik kepentingan dalam teori keagenan terjadi karena manajer memeiliki jumlah dan kualitas informasi yang jauh lebih banyak dibandingkan pihak eksternal perusahaan seperti kreditor dan investor. Fenomena tersebut dinamakan asimetri informasi. Asimetri informasi terjadi ketika manajer memiliki informasi internal perusahaan lebih banyak dan mengetahui informasi tersebut relatif lebih cepat dibandingkan pihak eksternal tersebut. Manajemen sebagai agen yang mengetahui lebih banyak informasi, memanfaatkan informasi yang tidak diketahui principal untuk memaksimalkan kepentingannya (Sartono, 2001).

Asimeteri informasi tersebut menimbulkan "penyakit" yang disebut dengan moral hazard dan adverse selection. Moral hazard merupakan tindakan manajer menciderai informasi yang disebabkan manajer lebih mengutamakan kepentingan pribadinya sehingga relatif tidak sesuai tuntunan moral yang baik. Selanjutnya, adverse selection adalah tindakan manajer dalam memilih informasi apa saja yang boleh/tidak boleh diungkapkan. Biasanya, manajer memilih informasi yang hanya sejalan dengan kepentingannya dan menyembunyikan informasi lainnya meskipun informasi tersebut masuk kategori informasi penting.

\section{Manajemen Laba}

Manajemen laba dapat dilihat dari dua perspektif, yaitu pelaporan keuangan dan kontraktual. Perspektif pelaporan keuangan menyatakan bahwa manajer menggunakan manajemen laba untuk :

1. Memenuhi ramalan analis laba sebagai upaya untuk menghindari kerusakan reputasi dan reaksi negatif dari harga saham yang terjadi secara cepat ketika ekspektasi investor gagal tercapai. Cara yang ditempuh manajer yaitu mencatat writeoff secara berlebihan atau menekankan pada penambahan laba selain laba bersih, seperti "pro-forma earnings". Beberapa taktik menunjukkan bahwa manajer tidak sepenuhnya menerima pasar modal .

2. Melaporkan pola laba yang stabil dan bertumbuh sepanjang waktu. Berdasarkan pasar modal efisien, hal tersebut menjadi hal yang diperlukan untuk menunjukkan informasi internal manajemen. Oleh karena itu, manajemen laba merupakan cara mengkomunikasikan informasi internal kepada investor. Perataan laba menjadi hal yang menarik dan mungkin mengejutkan, karena ternyata manajemen laba merupakan hal yang bermanfaat berdasarkan perspektif pelaporan keuangan. 
Manajemen laba yang berlebihan dapat mengurangi kegunaan laporan keuangan bagi investor, terutama jika manajer melakukan manajemen laba secara oportunistik dan tidak diungkapkan secara penuh. Perspektif kontraktual menyatakan bahwa manajer menggunakan manajemen laba untuk

1. Melindungi perusahaan dari konsekuensi atas peristiwa yang tidak tercantum dalam kontrak yang kaku dan tidak lengkap.

2. Mencapai kompensasi secara efisien. Hal tersebut karena kontrak kompensasi manajerial memungkinkan terjadinya manajemen laba dengan pertimbangan bahwa adanya biaya yang tinggi untuk mengeliminasi manajemen laba sama sekali.

Manajemen laba juga berpengaruh terhadap motivasi manajer untuk meningkatkan kinerja, karena manajer bisa menggunakan manajemen laba untuk menstabilkan kompensasi sepanjang waktu, sehingga mengurangi risiko kompensasi. Namun demikian, manajer perlu untuk menghindari risiko tertentu ketika mereka bekerja keras.

Cara manajer melakukan manajemen laba yang pertama adalah dengan memilih kebijakan akuntansi tertentu sesuai dengan tujuan mereka. Cara kedua yaitu melakukan aksi riil yang berdampak pada laba, seperti pemotongan biaya penelitian dan pengembangan.

Pentingnya informasi laba membuat manajemen terpacu untuk meningkatkan performa laba yang lebih baik melalui manajemen laba. Manajemen laba didefinisikan sebagai upaya manajer perusahaan untuk mengintervensi atau mempengaruhi informasi-informasi dalam laporan keuangan dengan tujuan untuk mengelabui stakeholder yang ingin mengetahui kinerja dan kondisi perusahaan (Sulistyanto, 2008:6). Jadi tujuan utama manajemen laba adalah untuk mengelabui, sehingga wajar jika manajemen memiliki konotasi yang negatif atau masuk kategori opportunistic perspective of earnings management.

Schipper (dalam Sulistyanto, 2008:49) menjelaskan bahwa manajemen laba adalah campur tangan dalam proses penyusunan pelaporan keuangan eksternal, dengan tujuan untuk memperoleh keuntungan pribadi (pihak yang tidak setuju mengatakan bahwa hal ini hanyalah upaya untuk memfasilitasi operasi yang tidak memihak dari sebuah proses). Cara melakukan manajemen laba bermacammacam. Cara yang paling umum diketahui adalah melalui manipulasi akrual. Cara yang lainnya adalah melalui manipulasi aktifitas riil. Kedua cara tersebut memerlukan keahlian khusus di bidang akuntansi, manajemen, dan keuangan sehingga ada yang menyebutnya sebagai kejahatan kerah putih.

\section{Perataan Laba}

Pola manajemen laba bermacam-macam yang tergantung pada tujuannya. Salah satu pola dari manajemen laba adalah perataan laba. Praktik perataan laba (income smoothing) adalah salah satu tindakan yang dilakukan manjemen untuk meningkatkan market returns (Michelson et.al.:2000). Market returns terkait dengan kinerja perusahaan melalui perspektif pasar modal. Pelaku pasar atau investor menyukai laba yang relatif bertumbuh secara gradual dan berkelanjutan. Perspektif mereka jangka panjang sehingga sadar bahwa return perusahaan yang 
berkualitas akan diperoleh dari laba yang bertumbuh secara positif, meski pertumbuhannya tidak cepat.

Manajer yang canggih (sophisticated) pasti dapat mengetahui perilaku investor yang demikian itu. Hal tersebut mendorong manajer untuk mengupayakan agar laba yang dilaporkan bisa bertumbuh sesuai dengan keinginan investor dengan harapan bahwa saham perusahaan akan mendapat penilaian yang bagus sehingga diminati oleh banyak investor. Cara yang dilakukan manajer agar mendapatkan pola laba yang demikian dinamakan perataan laba. Menurut Beidleman dalam Belkoui (2007:92), perataan dari laba yang dilaporkan dapat didefinisikan sebagai pengurangan atau fluktuasi yang disengaja terhadap tingkatan laba yang saat ini dianggap normal oleh perusahaan.

Menurut Ashari, dkk (1994) perataan laba adalah sinyal dari manjemen dalam memilih metode/kebijakan akuntansi di dalam standar akuntansi untuk meminimalkan fluktuasi yang berdampak pada performa perusahaan di masa datang. Selanjutnya, Copeland (1997) mengatakan bahwa perataan laba adalah pengurangan fluktuasi dari tahun ke tahun melalui pemindahan earnings dari tahun puncak untuk mengurangi periode kesuksesan. Sebenarnya tindakan tersebut diperkenankan oleh standar, namun masalahnya adalah di niat manajer. Ketika manajer berniat untuk mengelabui pihak eksternal, maka tindakan yang diperbolehkan tersebut secara hakikatnya adalah tindakan kriminal.

Pada manajemen laba berbasis kebijakan akuntasi, terdapat beberapa hal yang perlu diperhatikan. Pertama pilihan kebijakan akuntansi dibagi menjadi 2, yaitu kebijakan akuntansi per se dan kebijakan akuntansi diskresionari akrual. Kebijakan akuntansi per se misalnya pemilihan penggunaan metode amortisasi garis lurus atau saldo menurun serta kebijakan pengakuan pendapatan. Di sisi lain, kebijakan akuntansi diskresioneri akrual misalnya penentuan kerugian penjualan secara kredit, biaya garansi, penilaian persediaan, waktu dan jumlah item yang persistensinya rendah seperti writeoff, dan penentuan restrukturisasi.

Kedua, Konsekuensi manajemen laba berbasis kebijakan akuntansi (iron law) yaitu accrual reverse (akrual yang berkebalikan). Maksudnya adalah manajer yang mengatur laba agar meningkat dengan jumlah yang melebihi kemampuan untuk mempertahankannya, akan melakukan kebijakan akuntansi yang berkebalikan pada periode berikutnya sehingga mengakibatkan penurunan laba relatif dibandingkan peningkatan laba periode saat ini. Jika perusahaan memiliki kinerja yang buruk, maka tindakan manajemen laba tidak bisa secara langsung menunda hal tersebut. Oleh karena itu, kemungkinan manajemen laba menjadi hal yang baik jika hal tersebut tidak dilakukan sebagai sarana misleading atau fraudulent reporting. Namun jika manajemen laba tetap dilakukan, meski kondisi perusahaan buruk, maka hal tersebut disebut dengan kesalahan manajemen laba (earnings mismanagement).

Konsekuensi accrual reverse menunjukkan pentingnya penelitian tentang manajemen laba dengan metode multiple-period, sehingga diperoleh pemahaman yang lebih baik tentang (1) seberapa kuat kecenderungan perusahaan untuk melakukan manajemen laba?; (2) seberapa kuat pasar modal dan pasar tenaga kerja mengendalikan tindakan manajemen laba oportunistik. Biaya manajemen 
laba berbasis kebijakan akuntansi mahal seperti risiko pelaporan kecurangan akuntansi oleh auditor sebagaimana kasus Enron dan WorldCom.

\section{Faktor-Faktor yang Mempengaruhi Perataan Laba}

Beberapa penelitian mengenai faktor-faktor yang mempengaruhi perataan laba telah banyak dilakukan dengan hasil yang juga beragam. Penelitian ini bertujuan untuk mengkonfirmasi kembali penelitian mengenai faktor-faktor yang mempengaruhi perataan laba dengan hasil penelitian sebelumnya.

\section{Nilai Perusahaan}

Herawaty (2008) menyatakan bahwa nilai perusahaan merupakan pandangan investor terhadap perusahaan yang dikaitkan dengan harga saham. Perusahaan yang memiliki harga saham yang bagus biasanya disebut perusahaan besar dan akan mendapat lebih banyak perhatian dari berbagai pihak seperti, para analis, investor maupun pemerintah.

Harga saham adalah cerminan dari akumulasi perilaku investor. Harga dibentuk melalui proses permintaan dan penawaran. Ketika harga saham suatu perusahaan mendapatkan harga yang tinggi, maka dapat dikatakan bahwa saham tersebut diminati oleh banyak investor. Minat investor tersebut tentu saja timbul setelah melalui berbagai pertimbangan. Salah satu pertimbangan penting bagi investor adalah kinerja keuangan perusahaan, khususnya kualitas laba.

Ketika investor memberikan penilaian yang bagus terhadap saham perusahaan, maka dampaknya adalah pada nilai perusahaan. Nilai perusahaan menunjukkan kinerja perusahaan dalam perspektif pasar modal. Penilaian tersebut merupakan salah satu cara menilai perusahaan selain penilaian yang berbasis laporan keuangan (analisis fundamental). Nilai perusahaan dinilai lebih obyektif karena sumber informasi tidak semata pada laporan keuangan saja, namun juga menggunakan informasi berupa harga pasar saham.

Pengukuran nilai perusahaan sering kali dilakukan dengan menggunakan rasio-rasio penilaiaan atau rasio pasar. Rasio pasar merupakan ukuran kinerja yang paling menyeluruh untuk suatu perusahaan karena mencerminkan pengaruh gabungan dari rasio hasil pengembalian dari risiko. Menurut Weston dan Copeland (2008:244), rasio penilaian terdiri dari (1) Price Earning Ratio (PER), (2) Price to Book Value (PBV), dan (3) Tobin's Q Ratio.

\section{Pertumbuhan Pendapatan}

Pertumbuhan perusahaan adalah salah satu tujuan yang sangat diharapkan oleh pihak internal maupun eksternal suatu perusahaan karena memberikan suatu dampak yang baik bagi perusahaan maupun pihak-pihak yang berkepentingan terhadap perusahaan yaitu investor, kreditur dan pemegang saham. Pertumbuhan perusahaan merupakan dampak dari arus dana perusahaan dari perubahan operasional yang disebabkan oleh pertumbuhan atau penurunan volume usaha (Helfert, 1997).

Ada beberapa rasio yang digunakan untuk menghitung pertumbuhan perusahaan yaitu salah satunya dengan menggunakan proksi total pendapatan sesuai dengan penelitian yang dilakukan oleh Fricilia (2015) yaitu sebagai berikut: 


$$
\text { Growth }=\frac{\text { Total Pendapatan } \mathrm{t}-\text { Total Pendapatan } \mathrm{t}-1}{\text { Total Pendapatan } \mathrm{t}-1} \times 100 \%
$$

\section{Reputasi Auditor}

Jensen dan Meckling (1976) berpendapat bahwa pengauditan merupakan suatu proses pengawasan dan meningkatkan keselarasan informasi yang wujud antara manajemen dan pemegang saham. Pentingnya pengawasan auditor bagi perusahaan menjadikan kualitas audit menjadi hal penting yang harus diperhatikan. Menurut De Angelo (1981) kualitas audit merupakan kemampuan seorang auditor untuk menemukan suatu pelanggaran dalam pelaporan keuangan klien dan melaporkan pelanggaran tersebut.

Pengukuran kualitas audit sejauh ini umumnya menggunakan proksi ukuran KAP (Big Four vs non-Big Four). Hal ini didasarkan pada anggapan bahwa KAP Big Four memiliki pengetahuan, pengalaman, dan reputasi yang lebih baik dibandingkan KAP lainnya. Seperti yang dikemukakan oleh De Angelo (1981) bahwa kualitas audit meningkat sejalan dengan ukuran KAP, karena KAP besar mempunyai kemampuan lebih untuk berspesialisasi dan berinovasi melalui teknologi sehingga meningkatkan kemungkinan KAP besar untuk menemukan pelanggaran dalam sistem akuntansi perusahaan. Dengan adanya keunggulan sumber daya yang dimiliki oleh auditor dengan skala besar, maka auditor akan lebih dapat mendeteksi dan mengkoreksi kesalahan pelaporan keuangan perusahaan.

\section{KERANGKA PEMIKIRAN}

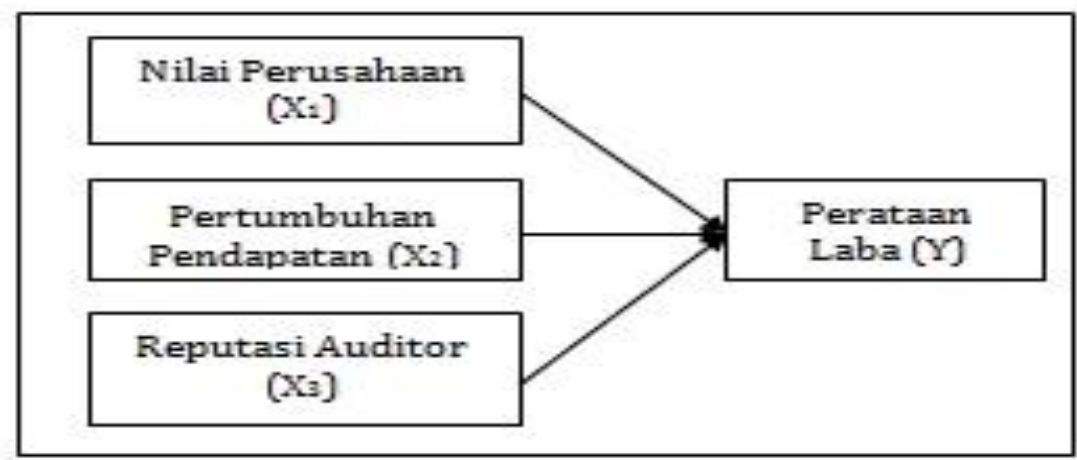

\section{Pengembangan Hipotesis}

\section{Pengaruh Nilai Perusahaan terhadap Perataan Laba}

Menurut Sudana (2009:7) tujuan suatu perusahaan adalah memaksimumkan nilai perusahaan atau kekayaan bagi pemegang saham. Pernyataan tersebut disandarkan pada teori keagenan yang menyatakan bahwa manajer memiliki mandat untuk mengelola perusahaan sebaik mungkin dengan tujuan yang sejalan dengan kepentingan prinsipal.

Penelitian Aji dan Mita (2010) menemukan hasil bahwa semakin tinggi nilai perusahaan maka kecenderung melakukan perataan laba lebih besar, dikarenakan nilai perusahaan yang baik dianggap laba yang dihasilkan perusahaan tersebut stabil sehingga menarik minat manajemen untuk melakukan perataan laba. Nilai 
perusahaan yang baik berarti citra perusahaan dianggap baik bagi investor sehingga investor berkeinginan membeli saham tersebut.

Ketika perusahaan sudah mendapatkan penilaian yang baik dari investor, maka perusahaan tersebut akan berusaha mempertahankannya atau bahkan meningkatkannya. Hal tersebut didorong oleh adanya peluang bagi perusahaan untuk mendapatkan tambahan modal dari investor baru maupun dari tambahan peningkatak volume dan harga saham yang sudah diepas di pasar modal. Selain itu, nilai perusahaan yang bagus juga memiliki nilai strategis bagi perusahaan. Perusahaan yang posisi nilai perusahaannya tinggi, maka bisa melakukan berbagai keputusan strategis jangka panjang yang sebelumnya tidak bisa dilakukan. Keleluasaaan itulah yang mendorong perusahaan yang memiliki nilai perusahaan bagus akan melakukan perataan laba. Hal tersebut mendapat dukungan empiris berdasarkan hasil penelitian Ansori (2014) dan Cahyani (2012) yang memberikan bukti empiris bahwa nilai perusahaan berpengaruh positif terhadap perataan laba.

\section{$\mathrm{H}_{1}$ : Nilai Perusahaan berpengaruh terhadap Perataan Laba}

\section{Pengaruh Pertumbuhan Perusahaan terhadap Perataan Laba}

Kim dkk. (2003) memaparkan bahwa perusahaan yang memiliki pertumbuhan pendapatan yang tinggi, kemungkinan tidak termotivasi dalam melakukan tindakan manipulasi laba. Sebaliknya jika perusahaan memiliki pertumbuhan pendapatan rendah, maka akan memiliki kecenderungan untuk menyesatkan laporan laba atau perubahan laba melalui tindakan manipulasi laba. Dengan demikian, tinggi rendahnya pertumbuhan pendapatan menjadi sumber variasi tindakan perataan laba. Pernyataan tersebut sesuai dengan hasil penelitian Fricilia (2015) yang berhasil membuktikan adanya pengaruh pertumbuhan perusahaan terhadap manajemen laba.

Ansori (2014) menyatakan bahwa pertumbuhan suatu perusahaan dalam sudut pandang investor merupakan suatu tanda perusahaan memiliki aspek yang menguntungkan sehingga pihak manajer berusaha untuk menunjukkan bahwa perusahaannya telah bertumbuh dengan baik. Sebagaimana telah dijelaskan sebelumnya bahwa investor hanya berminat pada perusahaan yang bertumbuh positif secara berkelanjutan. Pengetahuan tersebut mendorong manajer pada perusahaan yang pertumbuhan penjualannya tidak stabil, untuk melakukan perataan laba. Hal tersebut mengindikasikan bahwa untuk menjaga produktivitas dan menarik minat investor perlu dilakukannya praktik perataan laba.

\section{$\mathrm{H}_{2}$ : Pertumbuhan Perusahaan berpengaruh terhadap Perataan Laba 3. Pengaruh Reputasi Auditor terhadap Perataan Laba}

Mengidentifikasi praktik perataan laba bukanlah hal yang mudah. Perlu teknik dan kapasitas yang bagus bagi pemeriksa laporan keuangan untuk menentukan laba yang didalamnya terkandung untuk manajemen laba. Hal ini disebabkan manajemen laba adalah suatu hal yang bersifat pre-judice, hanya prasangka saja, tidak ada bukti melainkan hanya indikasi. Auditor yang bereputasi tentunya memiliki kapastias yang relatif lebih baik dibandingkan dengan KAP yang tidak bereputasi, sehingga auditor tersebut memiliki sensitifitas yang bagus untuk mengidentifikasi manejemen laba. Soselisa (2008) menyatakan bahwa 
kualitas audit yang lebih tinggi dari suatu Kantor Akuntan Publik (KAP) akan memperbesar risiko terungkapnya kecurangan akuntansi. Dengan demikian, terdapat indikasi bahwa KAP Big Four akan cenderung bertindak lebih objektif dalam menghasilkan kualitas audit yang lebih baik daripada KAP non-Big Four.

Penelitian Handayani (2016) menemukan bahwa kualitas auditor berpengaruh negatif terhadap praktik perataan laba. KAP The Big Four menghasilkan kualitas audit yang lebih tinggi dibandingkan KAP non The Big Four. KAP The Big Four dianggap lebih berkualitas karena auditor tersebut dibekali oleh serangkaian pelatihan dan prosedur audit yang dianggap lebih akurat dan efektif dibandingkan dengan auditor dari KAP non The Big Four. Penelitian tersebut juga konsisten dengan hasil penelitian Herni dan Susanto (2008) yang menyatakan adanya pengaruh reputasi auditor terhadap perataan laba.

\section{$\mathrm{H}_{3}$ : Reputasi Auditor berpengaruh terhadap Perataan Laba}

\section{METODE PENELITIAN}

\section{Jenis dan Objek Penelitian}

Jenis penelitian yang digunakan adalah penelitian dengan pendekatan kuantitatif. Selanjutnya, objek penelitiannya adalah perusahaan perbankan yang listing di Bursa Efek Indonesia (BEI) pada periode 2013 sampai dengan 2016. Penentuan periode amatan didasarkan pada pertimbangan kekinian data dan kesamaan periode implementasi IFRS di Indonesia

\section{Populasi dan Sampel}

Populasi dalam penelitian ini adalah seluruh perusahaan perbankan yang listing di Bursa Efek Indonesia (BEI) tahun 2013-2016. Teknik pengambilan sampel yang digunakan adalah purposive sampling yaitu pengambilan sampel berdasarkan kriteria.

Berikut tabel 1 yang menunjukkan kriteria pemilihan sampel beserta hasil identifikasi datanya:

\section{Tabel 1. Pemilihan Sampel}

\begin{tabular}{cllc}
\hline No & \multicolumn{1}{c}{ Kriteria } & Jumlah \\
\hline 1. & Perusahaan perbankan yang terdaftar di BEI & 34 \\
2. & Perusahaan yang delisting & $(1)$ & \\
3. & Perusahaan yang melakukan aksi korporasi & $(14)$ & \\
4. & Perusahaan yang rugi & $(2)$ & 17 \\
$\quad$ & $\quad$ Total Perusahaan Terpilih & 68 \\
& $\begin{array}{l}\text { Periode amatan 4 tahun, sehingga jumlah } \\
\text { perusahaan-tahun adalah 17x4 }\end{array}$ & \\
\hline
\end{tabular}

\section{Jenis dan Sumber Data}

Jenis data yang digunakan dalam penelitian ini adalah data sekunder. Selanjutnya, sumber data diperoleh dari situs resmi Bursa Efek Indonesia dan laman resmi dari masing-masing perusahaan perbankan. 


\section{Definisi operasional masing-masing variabel}

\section{Perataan Laba (Y)}

Variabel dependen dalam penelitian ini adalah perataan laba (Y). Perataan laba dalam penelitian ini diukur dengan menggunakan Indeks Eckel (1981) dengan rumus sebagai berikut :

$$
\text { Indeks Eckel }=\frac{\mathrm{CV} \Delta \mathrm{I}}{\mathrm{CV} \Delta \mathrm{S}}
$$

CV : Koefisien variasi dari variabel yaitu standar deviasi dibagi dengan rata-rata perubahan laba (I) atau pendapatan (S)

$\Delta \mathrm{I}:$ Perubahan Laba dalam satu periode

$\Delta S$ : Perubahan Pendapatan dalam satu periode

Nilai dari $\mathrm{CV} \Delta \mathrm{I}$ dan $\mathrm{CV} \Delta \mathrm{S}$ dapat dihitung dengan rumus :

$$
C V \Delta \mathrm{I} \text { atau } C V \Delta \mathrm{S}=\frac{\sqrt{\sum(\Delta \mathrm{X}-\overline{\Delta \mathrm{X}})^{2}}}{\mathrm{n}-1}: \overline{\Delta \mathrm{X}}
$$
berikut :

Adapun kriteria perusahaan yang melakukan perataan laba adalah sebagai

a. Perusahaan dianggap melakukan praktik perataan laba apabila indeks perataan laba lebih kecil dari $1(\mathrm{CV} \Delta \mathrm{S}>\mathrm{CV} \Delta \mathrm{I})$

b. Perusahaan dianggap tidak melakukan praktik perataan laba jika indeksnya lebih besar sama dengan $1(\mathrm{CV} \Delta \mathrm{S} \leq \mathrm{CV} \Delta \mathrm{I})$

Jadi apabila perusahaan sampel melakukan perataan laba akan diberi nilai 1, yang tidak melakukan perataan laba diberi nilai 0 .

\section{Nilai Perusahaan $\left(\mathbf{X}_{1}\right)$}

Nilai perusahaan dapat dihitung menggunakan rasio Price Book Value (PBV) yang dihasilkan dari rasio antara nilai pasar ekuitas perusahaan terhadap nilai buku ekuitas perusahaan (Aji dan Mita, 2010).

$$
P B V=\frac{\text { Harga Pasar per Lembar Saham }}{\text { Nilai Buku per Lembar Saham }}
$$

\section{Pertumbuhan Pendapatan $\left(\mathbf{X}_{2}\right)$}

Perhitungan variabel pertumbuhan perusahaan pada penelitian ini menggunakan proksi total pendapatan sesuai dengan penelitian Fricilia (2015) yang menggunakan pendekatan tersebut untuk perbankan.

$$
\text { Growth }=\frac{\text { Pendapatan } \mathrm{t}-\text { Pendapatan } \mathrm{t}-1}{\text { Pendapatan } \mathrm{t}-1} \times 100 \%
$$




\section{Reputasi Auditor $\left(\mathrm{X}_{4}\right)$}

Menurut Siregar dan Utama (2005), variabel kualitas audit diukur menggunakan variabel dummy. Jika perusahaan diaudit oleh KAP Big Four akan diberi nilai 1, dan jika diaudit oleh KAP Non Big Four diberi nilai 0.

Metode analisis yang digunakan dalam penelitian ini adalah metode analisis data kuantitatif dengan menggunakan program SPSS versi 2.1 sebagai alat untuk menguji data. Analisis regresi logistik digunakan untuk menguji pengaruh nilai perusahaan, pertumbuhan perusahaan, dan reputasi auditor terhadap perataan laba perusahaan perbankan yang terdaftar di BEI.

\section{HASIL DAN PEMBAHASAN}

\section{Hasil Uji Kesesuaian Model}

Langkah awal adalah menilai overall fit model terhadap data. Hipotesis untuk model fit adalah:

Ho: Modelyang dihipotesiskan fit dengan data

Ha: Model yang dihipotesiskan tidak fit dengan data.

Tabel 2

Hasil Uji Overall Model Fit

\begin{tabular}{llcr}
\hline Iteration & \multicolumn{2}{c}{$\begin{array}{c}\text {-2Log } \\
\text { likelihood }\end{array}$} & $\begin{array}{c}\text { Coefficients } \\
\text { Constant }\end{array}$ \\
\hline Step0 & 1 & 92,139 & 0,353 \\
& 2 & 92,139 & 0,357 \\
& 3 & 92,139 & 0,357 \\
\hline
\end{tabular}

Pada Tabel 2, nilai -2LogL awal yang hanya memasukkan konstanta adalah sebesar 92,139. Selanjutnya, tabel tersebut juga menunjukkan nilai -2LogL yang memasukkan konstanta dan variabel independen turun menjadi 82,981. Makna angka-angka tersebut adalah bahwa $-2 \log L$ block number $=0>-2 \log L$ block number $=1$. Dengan demikian diperoleh simpulan bahwa regresi dapat dikatakan baik sehingga pengujian selanjutnya dapat dilakukan.

Tabel 3

Model Summary

\begin{tabular}{|c|c|c|c|}
\hline \multirow[t]{2}{*}{ Step } & \multicolumn{3}{|c|}{ Cox\& Snell R } \\
\hline & -2Log likelihood & Square & Nagelkerke R Square \\
\hline 1 & $82,981^{3}$ & 0,126 & 0,170 \\
\hline
\end{tabular}

Selanjutnya pada Tabel 3 menunjukkan bahwa nilai Cox \& Snell $R$ Square sebesar 0,126 dan Nagelkerke $R$ Square sebesar 0,170 yang berarti variabilitas variabel dependen (perataan laba) dapat dijelaskan oleh variabilitas variabel independen (nilai perusahaan, pertumbuhan perusahaan, dan reputasi auditor) 
sebesar $17 \%$. Selanjutnya, $83 \%$ variabilitas pada variabel dependen dijelaskan oleh faktor-faktor lain diluar variabel independen yang digunakan. Maknanya, variabel-variabel independen yang diteliti memiliki kontribusi dalam menjelaskan variasi perataan laba, meskipun kontribusinya relatif kecil.

\section{Tabel 4}

Hasil Uji Goodness of Fit Test

\begin{tabular}{cccc}
\hline Step & Chisulare & df & Sig. \\
\hline 1 & 3782 & 8 & 0.876 \\
\hline
\end{tabular}

Tabel 4 merupakan hasil dari nilai statistik Hosmer and Lomoshow Goodness of Fit Test. Hasil menunjukkan bahwa nilai Chi-square sebesar 3,782 dengan probabilitas signifikansi 0,876. Nilai tersebut lebih besar dari 0,05 . Hasil tersebut menunjukkan bahwa Ho tidak ditolak yang berarti model regresi layak untuk dipakai.

\section{Hasil Uji Hipotesis}

Setelah dipastikan bahwa model yang disusun telah memenuhi syarat kelayakan, maka langkah selanjutnya adalah pengujian hipotesis. Pengujian hipotesis menggunakan alat regresi logistik dan rangkuman hasil pengujiannya disajikan dalam Tabel 5.

Tabel 5

Hasil Uji Hipotesis

\begin{tabular}{|c|c|c|c|}
\hline Hipotesis & B & Hasis (sig) & Simpulan \\
\hline$H_{1}$ & 0,728 & $0,0380^{487}$ & Terdukung \\
\hline $\mathrm{H}_{2}$ & $-1,140$ & $0,064^{4+16}$ & Terdokung \\
\hline $\mathrm{H}_{3}$ & 0,174 & 0,750 & Tidak Terdukung \\
\hline 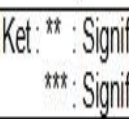 & $\begin{array}{l}\text { aaphla } 5 \\
\text { alapha } 1\end{array}$ & & \\
\hline
\end{tabular}

Hasil pengujian sebagai nampak pada Tabel 5 menunjukkan bahwa pada pengujian hipotesis 1 diperoleh nilai koefisien variabel $\mathrm{X}_{1}$ (nilai perusahaan) yaitu sebesar 0,728 dengan $p$-value 0,038. Nilai tersebut lebih rendah dari $\alpha$ yang ditetapkan yaitu $5 \%(0,038<0,05)$. Dengan demikian hipotesis 1 terdukung oleh data secara empiris. Maknanya, nilai perusahaan berpengaruh positif dan signifikan terhadap perataan laba.

Hal tersebut disebabkan semakin tinggi nilai perusahaan, maka kecenderung melakukan perataan laba lebih besar dikarenakan nilai perusahaan yang baik 
dianggap laba yang dihasilkan perusahaan tersebut stabil sehingga menarik minat manajemen untuk melakukan perataan laba. Nilai perusahaan yang baik mengartikan bahwa citra perusahaan dianggap baik bagi investor sehingga investor berkeinginan membeli saham tersebut (Aji dan Mita, 2010).

Bukti tersebut menguatkan argumentansi terkait teori keagenan. Secara tersirat, bukti empiris tersebut menunjukkan bahwa manajer sebagai agen memiliki komitmen yang besar untuk melanggengkan keberadaan perusahaan, bahkan manajer berupaya keras untuk meningkatkan nilai perusahaan. Salah satu usaha tersebut adalah melalui tindakan perataan laba.

Makna lain dari temuan ini adalah bahwa ada risiko yang melekat pada perusahaan yang memiliki nilai perusahaan yang tinggi. Identifikasi risiko berdasarkan tanda koefisien yang positif. Tanda positif menunjukkan bahwa semakin tinggi nilai perusahaan, maka manajer semakin agresif melakukan perataan laba.

Risiko tersebut muncul dari tindakan perataan laba yang agresif. Meskipun tujuan manajer melakukan perataan laba adalah demi kepentingan pemilik perusahaan (dalam hal ini pemegang saham), namun jika tindakan tersebut dilakukan secara terus menerus, maka akan berdampak buruk pada penilaian perusahaan di masa mendatang, apalagi jika teknik perataan laba yang dilakukan adalah berbasis akuntansi akrual. Temuan ini menjadi menarik untuk dikonfirmasi oleh peneliti selanjutnya.

Hal yang menarik lainnya adalah terkait dengan amatan penelitian yang menggunakan industri perbankan. Industri perbankan adalah industri yang "fully regulated". Tiap geraknya diatur oleh Otoritas Jasa Keuangan. Jika sampai bukti ini benar-benar nyata, maka masyarakat pasti akan terdampak karena nilai perusahaan yang tinggi justru menjadi pemicu tingginya tindakan yang tidak benar.

Hasil penelitian ini mengkonfirmasi pernyataan Scott (2012) bahwa perataan laba dapat dilihat dari dua perspektif, yaitu pelaporan keuangan dan kontraktual. Perspektif pelaporan keuangan menyatakan bahwa manajer menggunakan manajemen laba untuk memenuhi ramalan analis laba sebagai upaya untuk menghindari kerusakan reputasi dan reaksi negatif dari harga saham yang terjadi secara cepat ketika ekspektasi investor gagal tercapai. Cara yang ditempuh manajer yaitu mencatat writeoff secara berlebihan atau menekankan pada penambahan laba selain laba bersih, seperti "pro-forma earnings".

Beberapa taktik menunjukkan bahwa manajer tidak sepenuhnya menerima hipotesis pasar modal. Beberapa penelitian melaporkan pola laba yang stabil dan bertumbuh sepanjang waktu. Berdasarkan pasar modal efisien, hal tersebut menjadi hal yang diperlukan untuk menunjukkan informasi internal manajemen. Oleh karena itu, manajemen laba merupakan cara mengkomunikasikan informasi internal kepada investor. Perataan laba menjadi hal yang menarik dan mungkin mengejutkan, karena ternyata manajemen laba merupakan hal yang bermanfaat berdasarkan perspektif pelaporan keuangan

\section{Pengaruh Pertumbuhan Perusahaan Terhadap Perataan Laba}

Berdasarkan analisis data, diperoleh hasil berupa bukti empiris yang menunjukkan bahwa variabel pertumbuhan perusahaan memiliki $p$-value yang 
lebih rendah dari $\alpha$ yang ditetapkan $10 \%$, yaitu sebesar $0,064<0,010$. Dengan demikian, hasil tersebut menunjukkan bahwa pertumbuhan perusahaan berpengaruh signifikan terhadap probabilitas perataan laba, sehingga $\mathrm{H}_{2}$ diterima.

Selain itu, koefisien untuk variabel pertumbuhan perusahaan menunjukkan tanda negatif. Hal tersebut menunjukkan makna bahwa semakin tinggi pertumbuhan perusahaan, maka semakin kecil probabilitas manajer melakukan perataan laba.

Penjelasan atas temuan bukti empiris tersebut antara lain diperoleh dari penelitian Kim dkk (2003). Peneliti tersebut menyatakan bahwa pertumbuhan pendapatan yang dimiliki perusahaan dapat memotivasi manajer dalam memperoleh laba. Apabila perusahaan memperoleh pertumbuhan pendapatan yang rendah, maka manajer akan memiliki kecenderungan untuk memanipulasi laba.

Ketika perusahaan memiliki kinerja penjualan yang tinggi, maka manajer tidak lagi perlu khawatir dengan penilaian kinerja mereka. Basis aktifitas yang demikian tentunya secara langsung berdampak pada peningkatan laba, karena sumber utama laba adalah dari penjualan. Jadi, meski tanpa intervensi akrual berupa perataan laba, manajer bisa melaporkan kinerja terbaik mereka. Itulah mengapa, semakin tinggi penjualan maka semakin kecil probabilitas manajer melakukan perataan laba.

Kondisi sebaliknya adalah jika perusahaan memiliki pertumbuhan penjualan yang rendah, maka manajer pasti merasa khawatir akan penilaian kinerjanya. Baik kinerja manajerial maupun kinerja perusahaan. Ketika manajer mengetahui konsekuensi tersebut, maka mereka memiliki motivasi untuk melakukan intervensi akrual, yaitu dengan melakukan perataan laba. Hal tersebut dilakukan untuk mengantisipasi konsekuensi buruk maupun untuk menyelamatkan reputasi perusahaan. Dengan demikian, semakin rendah pertumbuhan penjualan, maka manaher semakin berani melakukan perataan laba.

Hasil penelitian ini konsisten dengan hasil penelitian yang dilakukan oleh Handayani (2009) dan Fricilia (2015). Dengan demikian, bukti empiris ini semakin memperkuat penelitian tersebut. Selain itu, pembuktian ini juga menunjukkan pentingnya kewaspadaan dalam menilai laba sebab angka laba diperoleh melalui sistem akuntansi akrual yang memungkinkan terakomodasinya kepentingan manajer yang bisa jadi bertentangan dengan kepentingan pemilik perusahaan.

Tucker dan Zarowin (2006) menduga perataan laba dapat meningkatkan kemampuan investor untuk memprediksi laba masa depan, sehingga seharusnya respon return saham terhadap laba akan meningkat, dengan asumsi pasar modal efisien. Sebaliknya, jika perataan laba mengakibatkan investor sulit untuk memprediksi laba masa depan, maka respon return saham menjadi menurun. Bukti empiris penelitian tersebut menunjukkan bahwa semakin tinggi perilaku perataan laba maka semakin tinggi respon pasar. Bukti tersebut konsisten dengan argumentasi sisi baik dari manajemen laba.

\section{Pengaruh Reputasi Auditor Terhadap Perataan Laba}

Hasil analisis data menunjukkan bahwa variabel reputasi auditor memiliki nilai signifikansi hitung yang lebih besar, yaitu sebesar 0,750 >0,05. Hasil 
tersebut menjelaskan bahwa reputasi auditor tidak berpengaruh terhadap perataan laba, sehingga $\mathrm{H}_{3}$ ditolak.

Hasil yang tidak signifikan mengenai pengaruh reputasi auditor terhadap perataan laba dapat dikarenakan perusahaan adalah pihak yang mengontrol seluruh kondisi perusahaan. Kondisi tersebut membuat perusahaan merupakan pihak yang mengetahui seluruh isi dari laporan keuangan yang sebenarnya sedangkan pihak auditor hanya merupakan pihak independen yang mengaudit kesesuaian laporan keuangan dengan standar yang telah ditetapkan dengan berdasarkan pada apa yang telah disajikan oleh perusahaan (Rice, 2013).

Selain itu, tidak berpengaruhnya reputasi auditor terhadap perataan laba juga bisa disebabkan oleh perusahaan menggunakan jasa dari KAP yang sama secara terus menerus selama beberapa tahun dengan tidak melakukan pergantian. Dengan demikian, KAP memiliki pemahaman atau perspektif yang sama dengan manajer. Pergantian KAP seharusnya perlu dilakukan. Hal tersebut dimaksudkan untuk menjaga agar tidak terganggunya independensi auditor dalam melakukan pemeriksaan terhadap laporan keuangan (Sulistiyawati, 2013). Penelitian ini membuktikan bahwa jenis Kantor Akuntan Publik (KAP) yang tergolong The Big Four ataupun Non The Big Four tidak mempengaruhi pilihan manajemen untuk melakukan perataan laba.

\section{SIMPULAN}

Berdasarkan hasil pengujian dan analisis hasil penelitian, maka dapat ditarik simpulan sebagai berikut:

1. Hasil pengujian untuk perataan laba $\mathrm{H}_{1}$ menunjukkan bahwa nilai perusahaan berpengaruh terhadap perataan laba perusahaan perbankan.

2. Hasil pengujian untuk perataan laba $\mathrm{H}_{2}$ menunjukkan bahwa pertumbuhan perusahaan berpengaruh terhadap perataan laba perusahaan perbankan.

3. Hasil pengujian untuk perataan laba $\mathrm{H}_{3}$ menunjukkan bahwa reputasi auditor tidak berpengaruh terhadap perataan laba perusahaan perbankan.

\section{SARAN}

Berdasarkan hasil penelitian, pembahasan, dan simpulan maka saran untuk penelitian selanjutnya yaitu :

1. Untuk pengukuran perataan laba dapat menggunakan alat lain selain indeks Eckel, seperti menggunakan model discretionary accrual dengan modified Jones dalam Kothari dkk. (2005)

2. Dapat memperluas sampel penelitian untuk mengklasifikasi perusahaan yang melakukan perataan laba dan tidak melakukan perataan laba

3. Penelitian selanjutnya dapat menambah variabel lain seperti rasio CAMEL yang digunakan sebagai pengukuran tingkat kesehatan Bank untuk lebih memperkuat hasil dari tindakan perataan laba. 


\section{DAFTAR PUSTAKA}

Aji, D. Y. dan A. F. Mita. 2010. Pengaruh Profitabilitas, Risiko Keuangan, Nilai Perusahaan, dan Struktur Kepemilikan Terhadap Praktek Perataan Laba: Studi Empiris Perusahaan Manufaktur Yang Tardaftar di BEI. Simposium Nasional Akuntansi XIII Purwokerto

Beattie, Vivien, Stephen, B. David, E. Brian, J. Stuart, M. Dylan, T. and Michael, T. 1994. Extraordinary Item and Income Smoothing: A Positive Accounting Approach. Journal of Business Finance and Accounting. Vol 21, No.6

Belkaoui, Ahmed. 2007. Teori Akuntansi. Jilid 2. Jakarta : Salemba Empat.

Cohen, D. A., dan Zarowin, P. 2010. Accrual-Based And Real Earnings Management Activities Around Seasoned Equity Offerings. Journal Of Accounting And Economics, 50(1), 2-19.

Eckel, N. 1981. The Income Smooting Hypothesis Revisited. Abacus, Vol 17, No. 1, Hal 28-40

Fricilia, \& Lukman, H. 2015. Analisis Faktor-Faktor yang Mempengaruhi Praktik Manajemen Laba pada Industri Perbankan di Indonesia. Jurnal Akuntansi. Vol 19, No.1, Hal 79-92.

Gunny, K. 2010. The Relation Between Earnings Management Using Real Activities Manipulation and Future Performance: Evidence From Meeting Earnings Benchmarks. Contemporary Accounting Research, 27(3), 855-888

Handayani dan Rachadi. 2009. Pengaruh Ukuran Perusahaan terhadap Manajemen Laba. Jurnal Bisnis dan Akuntansi, Vol 11, No.1, Hal 33-56

Handayani. 2016. Pengaruh Mekanisme Corporate Governance terhadap Praktik Perataan Laba. Jurnal of Accounting, Vol 2, No.2.

Helfert, Erich A. 1997. Teknik Analisis Keuangan. Terjemahan, Herman Wibowo. Edisi Kedelapan. Erlangga. Jakarta

Herawaty, Vinola. 2008. Peran Praktek Corporate Governance Sebagai Moderating Variabel dari Pengaruh Earning Management Terhadap Nilai Perusahaan. Jurnal Akuntansi dan Keuangan, Vol 10, No.2, Hal 97-108.

Hwihanus dan H. Qurba. 2010. Faktor-Faktor yang Mempengaruhi Manajemen Laba pada Perusahaan Industri yang Terdaftar di BEI. Jurnal Ekonomi dan Bisnis. Vol.14, No.1. Hal 1-6

Ikatan Akuntan Indonesia. 2012. Standar Akuntansi Keuangan. IAI. Jakarta

Jensen dan Meckling. 1976. Theory of the Firm Managerial Behavior Agency Costs and Ownership Structure. Journal of Financial Economics. Vol 3, No. 4, Hal 305-360.

Joosten, C. 2012. Real Earnings Management and Accrual-Based Earnings Management as Substitutes, Master Thesis, Department Accountancy Faculty of Economics and Business Studies Tilburg University

Kim, Y., Liu, C., \& Rhee, S. 2003. The Relation of Earnings Management and Firm Size. Working Paper. University of Hawai

Kuo, J. M., Ning, L., dan Song, X. 2014. The Real and Accrual-based Earnings Management Behaviors: Evidence from the Split Share Structure 
Reform in China. The International Journal of Accounting, Vol. 49, $101-136$

Laksmana, I dan Yang, Y. 2014. Product market competition and earnings management: Evidence from discretionary accruals and real activity manipulation. Advances in Accounting, incorporating Advances in International Accounting, 30, 263-275

Michelson, et. al. 2000. The Relationship between the Smoothing of Reported Income and Risk Adjusted Returns. Journal of Economics and Finance, Vol 24, No.2, Hal 141-159

Roychowdhury, S. 2006. Earnings Management Through Real Activities Manipulation. Journal of Accounting and Economics, 42, 335-370

Soselisa, Rangga dan Mukhlasin. 2008. Pengaruh Faktor Kultur Organisasi, Manajemen, Strategik, Keuangan dan Auditor terhadap Kecenderungan Kecurangan Akuntansi. Simposium Nasional Akuntansi XI. Pontianak.

Sulistiyawati. 2013. Pengaruh Nilai Perusahaan, Kebijakan Dividen, dan Reputasi Auditor terhadap Perataan Laba. Accounting Analysis Journal, Vol 2, No.2, Hal 148-153

Sulistyanto, Sri. 2008. Manajemen Laba : Teori dan Model Empiris. PT. Gramedia Widiasarana Indonesia. Jakarta

Tucker, J. F., dan Zarowin, P. 2006. Does Income Smoothing Improve Earnings Informativeness?. The Accounting Review, 81(1), 251-270

$\mathrm{Yu}, \mathrm{Q}, \mathrm{Du}, \mathrm{B}$. dan Sun, Q. 2006. Earnings Management at Rights Issues Thresholds-Evidence From China. Journal of Banking and Finance, 30, 3453-3468 